\title{
Children Circuit Model For Kids Physical Activity Based Blended Learning
}

\author{
Apta Mylsidayu, James Tangkudung, Sofyan Hanif, Bujang, Dindin Abidin
}

\begin{abstract}
This study aims to know whether"children's circuit models" for children's physical activity based blended learning can have an influence on children's endurance. The research sample consisted of 49 students first grade elementary school of IT Darussalam Cikarang, Bekasi Regency and accompanied by their parents. Kids endurance test using modification Harvard Steps Test. There was a significant difference, $(p<0.05)$ between pre-test and post-test in experiment and control group for kids edurance. Independent t-test revealed significant difference between pre test and post test in experiment group $(0.000<0.05)$, but no significant difference between pre test and post test in control group $(0.107>0.05)$. These results suggest that endurance, as a measure of physical activity intensity, should be closely monitored during research that is intended to make inferences about its the effects "children circuit model" as participation in vigorous activities have specific benefits for body over lower intensities.
\end{abstract}

Keywords: children circuit model, kids, physical activity, blanded learning.

\section{INTRODUCTION}

Physical inactivity is a modifiable risk factor for cardiovascular isease and a widening variety of other chronic diseases, including diabetes mellitus, cancer (colon and breast), obesity, hypertension, bone and joint diseases (osteoporosis and osteoarthritis), and depression (Warburton, Nicol, \& Bredin, 2006). Unfortunately, our knowledge physical activity benefits for health is still rather limited. Lack of physical activity and sedentary lifestyle in school-age children is a global health problem in both developed and developing countries (Mandic, Bengoechea, Stevens, Leon de la Barra, \& Skidmore, 2012). Furthermore, lack of physical activity is hypothesized to be an important contributing factor in the development and/or maintenance of childhood obesity (Trost, Kerr, Ward, \& Pate, 2001).

Physical activity is important to children's physical health and well-being (Tappe, Glanz, Sallis, Zhou, \& Saelens, 2013). Physical activity participation in childhood is essential for optimal physical and psychological health (Oliver et al., 2011). Children's participation in physical activity is different from that of adults, as they incrementally waver between low and high intensities, through short bursts of movement (Castelli, Hillman, Hirsch, Hirsch, \& Drollette, 2011)

\footnotetext{
Revised Manuscript Received on April 19, 2019.

Apta Mylsidayu, Doctoral Student, Postgraduate, Universitas Negeri Jakarta, Jakarta, Indonesia

James Tangkudung, Prof. Dr., Universitas Negeri Jakarta, Jakarta, Indonesia

Sofyan Hanif, Prof. Dr., Universitas Negeri Jakarta, Jakarta, Indonesia

Bujang, Doctoral Student, Postgraduate, Universitas Negeri Jakarta, Jakarta, Indonesia

Dindin Abidin, Dr., Universitas Islam 45 Bekasi, West Java, Indonesia
}

Diverse physical activity will have an impact on children's endurance. Endurance is always closely related to the length of work (duration) and the intensity of work, the longer the duration of exercise and the higher the intensity of work that can be done someone, means that the person has good endurance (Mylsidayu, 2019). Endurance can be defined as the capacity to sustain a given velocity or power output for the longest possible time (Jones \& Carter, 2000).

The results of observations on physical education learning in schools indicate that the teacher's learning method still uses the command learning and assignment approach. Learning runs smoothly but there are some students who are less interested in learning. This is because the teacher is not aware of the variations in the learning model, besides that the teacher is only guided by the printed book provided by the school. Thus, teachers feel the need to apply more varied methods of teaching physical education and adapted to increasingly sophisticated technology.

Physical activity for children can be done through the circuit method. Circuit training method is a method of organizing physical training given in the form of a circuit with a specific training load setting to improve and improve the ability of physical conditions (Hanif, 2015). In the circuit method usually consists of several items (kinds) of exercises that must be done in a certain time. After completing one training item, immediately move to another training item without recovery time or interval, and so on until all training items are completed, so that it is said to have done one circuit.

The use of communication technology such as blended learning for learning activities in universities in Indonesia is increasingly conducive to the development of increasingly rapid and accessible technology so that more human resources who can utilize this technology encourage conventional universities to conduct distance education.

The development of the blended learning model in sports education designed by adopting one of the learning models is supported by system facilities that can study anytime and anywhere without being limited by distance, space and time and varied learning materials so as to improve the quality of learning efficiently and effectively. The material taken is on children's physical activity using "children circuit model". "Children circuit model" is the result of research and development in the form of physical activity for children consisting of various kinds of basic movements that have been adapted to the characteristics of the child.

Published By:

Blue Eyes Intelligence Engineering

$\&$ Sciences Publication 


\section{LITERATURE}

\section{A. Concept of Model Development}

The model illustrates the existence of thinking patterns. A model usually describes the whole concept that is interrelated. Models help to overcome students' problems in exploring ideas (Joice \& Weil, 2009). Models help represent the reality of concepts, models are simple representations of more complex forms of processes, functions of phenomena or ideas to describe reality that is too complicated (Branch, 2002).

The use of learning design models can describe the objectives to be achieved. what is meant by design is a process for determining learning conditions (Richey \& Klein, 2012). In addition, design is also seen as a process for producing plans or blueprints in an effort to develop material that supports learning (Gagne, 2005).

The learning system design model usually describes the steps or procedures that need to be taken to create effective, efficient and interesting learning activities. In general, every learning system design is unique and different in the steps and procedures used. However, these design models have the same basic principles in the effort to design quality learning programs. Instructional Design is an important component and is related to other components. Learning instructors, learners, learning materials, learning activities, delivery systems, and learning environments interact and cooperate in an instructional design to achieve the desired learning goals. Understanding of instructional design is very important and needed in order to improve the quality of teaching and training (Dick, Carey \& Carey, 2009). Basically the learning process occurs with or without instructional design, but each learning process will be influenced by things that are external to a learner (Reighluth, 2009). Instructional design is made with the aim of making learning more effective, efficient, and easier (Morrison, at al, 2007).

\section{B. Concept of Developed Models}

The development of this model is based on several concepts that are considered supportive. The model developed is a learning model in the blended learning "Motor Learning" course. Learning is the process of a combination that consists of human, material, facilities, equipment and procedures that influence each other to achieve learning goals.

E-learning is a concept that changes the form of teaching and learning by using the sophistication of information systems / information techniques (Evelyn, Kigozi \& Kahiigi, 2008). One of the advantages of e-learning is the ability to carry out distance learning by using the internet. Michael (2013). defines E-learning as Learning which is arranged with the aim of using an electronic system or computer so that it can support the learning process.

With E-learning allows the occurrence of the distance learning process. E-learning is the basis of the development of information and communication technology. With Elearning, students do not need to sit sweetly in the classroom to listen to each greeting from a teacher directly. E-learning can also shorten the target schedule of learning time and of course save the costs that must be incurred by a learning program. E-learning also known as "Virtual Classroom" is a concept in the learning process using information and communication technology (Darmayanti, 2007).

The term 'blended learning' has been a trend in recent years as a description of certain forms of teaching with technology (Oliver \& Trigwell, 2005). "Blended Learning" provides a practical overview of the technologies currently available (Tyley, 2012). It combines basic information for technology beginners with sophisticated ideas for using technology in learning. The source of this transformation comes from the ability of online students to be together and separate - and to connect to the student community anytime and anywhere, without being bound by time, place or situation (Garrison \& Kanuka, 2004).

Horn and Staker (2015) stated that blended learning is a formal education program where students study online and face to face directly in the classroom. In online learning, students have control over their own time, place and / or speed. Similar definitions are given by Garrison and Vaughan (2008) which state blended learning "is a coherent design approach that openly assesses and integrates the strengths of face-toface and online learning to address worthwhile educational goals". MacDonal (2008) described blended learning as "the principled adoption of strategies and media to support course objectives and enhance responsiveness to student needs".

Blended learning, according to Thorne (2003), integrates the innovative advances and technologies offered by online learning with the interactions and participation offered in traditional learning. Blended learning should be seen as a pedagogical approach that combines face-to-face and online learning that is able to increase interaction, not just a mere means of delivering learning. The intended interaction is the interaction between students and the interaction between students and lecturers (Khe, \& Cheung, 2014)

\section{Motoric Learning}

Motoric development is one of the most important factors in the development of the individual as a whole. Physical skills needed by children for sports activities and activities can be studied and trained in the early stages of development. It is very important to learn these skills with a pleasant atmosphere, not to compete so that children learn sports with pleasure and feel comfortable participating. Avoid games where someone or a group of people win and the other group loses. Children who continuously lose in a game have a tendency to feel less confident in their abilities and will stop participating. The purpose of physical education for young children is to develop skills and long-term physical attraction.

Motoric development is the process of developing a child's ability to move. Basically, this development develops along with the maturity of the nerves and muscles of the child. So, any movement as simple as anything, is the result of a complex pattern of interactions of various parts and systems in the body that are controlled by the brain. Physical development is closely related to children's motor 
development. Motoric is the development of controlling body movements through coordinated activities between the nervous system, muscles and brain.

Motoric development is different in level for each individual. Four-year-olds can easily use scissors while others may be able to make it after five or six years. Certain children might be able to easily catch and catch the ball while others might only be able to catch a large ball or roll around. Likewise environmental stimulation, nutritional status, race and genetics have important influences on motoric development.

Motoric learning is defined as the learning process of movement skills and refinement of motor skills and variables that support or inhibit motor skills. There are four concepts that are reflected in motor learning, namely: (1) Learning is a process of gaining ability for skilled action. (2) The lesson is caused by experience or practice. (3) Lessons cannot be measured directly; instead is inferred from behavior. (4) Relative learning outcomes have permanent changes in behavior.

\section{D. "Children Circuit Model"}

Children Circuit Model is Learning by maximizing the empowerment of thoughts and feelings with increasing patterns and repeating the pattern of letters in words CHILDREN.

The contents of physical activities "children circuit model" are as follows:

\section{C Circuit}

Target: locomotor, non locomotor, and manipulative. Tools: (1) 3 pieces of marker, (2) 7 pieces of cones, (3) meters, (4) 4 pieces of basketball, (5) 4 pieces of patchwork, (6) 1 piece of box, (7) whistle. Play area: 7 x 5 meters. Implementation procedure: students do: (1) Position students squat then roll the basketball on the floor to the right and left (2 times each), (2) Then walk on tiptoe around the cones while holding the basketball above the head until heading 2, (3) From post 2 to post 3 do the rabbit jump by holding the ball in front of the chest, (4) Arriving at post 3, basketball is placed in a box and students take a patchwork fabric and do the catching as much as $3 x$, and ( 5) The second student follows after the first student arrives at post 2 .

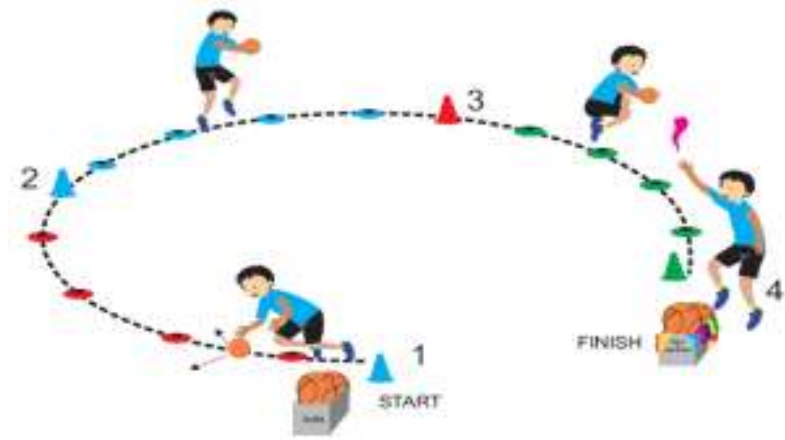

Figure 1. Sirkuit C

\section{2. $\quad H$ Circuit}

Target: locomotor, non locomotor, and manipulative. Tools: ladder (5), cone cones (5), bowl cones (7), boxes (1), patchwork (5). Play area: 7 x 5 meters. Procedure: (1) hitting the ball, (2) running open the leg cap, (3) walking while turning the patch, (4) congklang four left four right then running to the finish line.

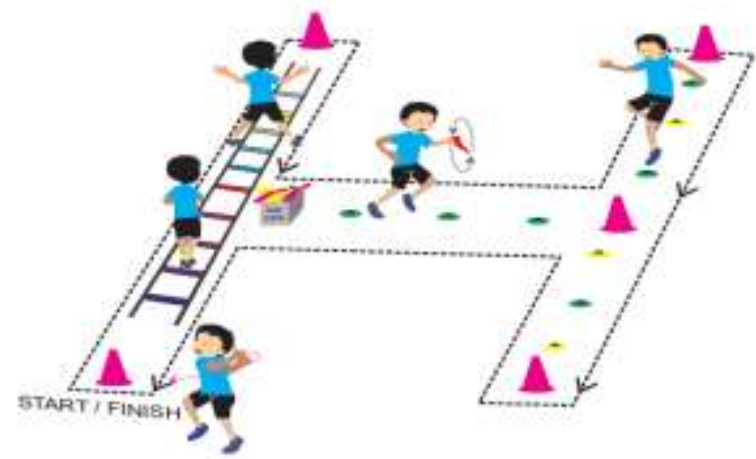

Figure 2. Sirkuit $\mathbf{H}$

\section{I Circuit}

Target: locomotor, non locomotor, and manipulative. Tools: ball smile (5), box (1), cone cones (2), ladder $5 \mathrm{~m}$ (1). Play area: 7 x 1 meter. Procedure: students do: (1) 3x volleyball downward passing, (2) jogging with the right foot in the leader, (3) look for 2 smile balls then squeeze $3 x$ (right and left hand together), and (4) jogging with your left foot in the leader until the finish line.

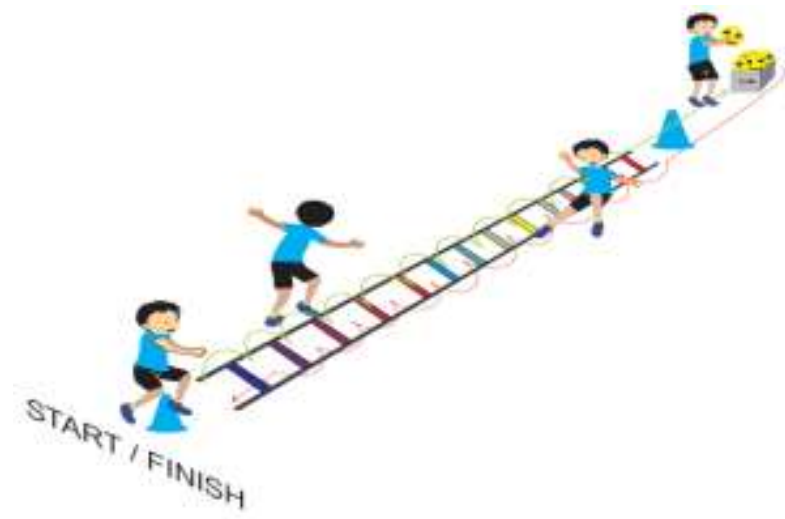

Figure 3. Sirkuit I

\section{L Circuit}

Target: locomotor, non locomotor, and manipulative. Tool: $60 \mathrm{~cm}$ wicket (2), 20 straight goal wicks while carrying cones and balls, and (4) $\mathrm{cm}$ (2), bowl cones (3), cone cones (6), basketball (5), squares (1). Play area: 4 x 8 meters. Procedure: students do: (1) jump spinning, (2) crawl jump (3) road over roll the ball on the foot twice.

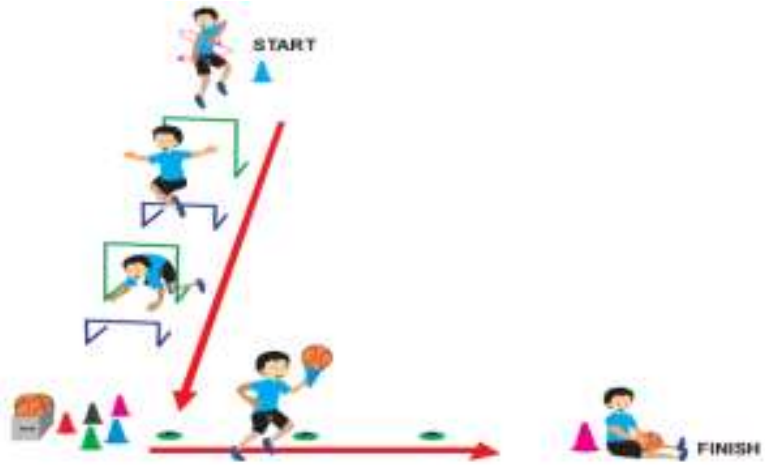

Figure 4. Sirkuit L

Published By: Blue Eyes Intelligence Engineering \& Sciences Publication 


\section{D Circuit}

Target: locomotor, non locomotor, and manipulative. Tools: colorful balls (5), cones (10), boxes (2). Play area: 7 x 5 meters. Procedure: students do: (1) jump three times, (2) take the ball and then carry the ball to touch the head, chest, knees, feet, (3) run like a bird, and (4) crawl over the cones.

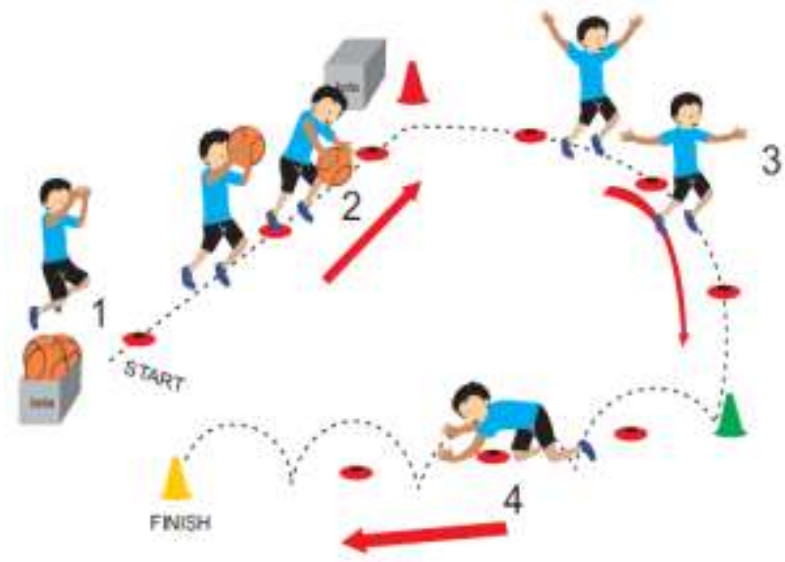

Figure 5. Sirkuit D

\section{6. $\quad$ R Circuit}

Target: locomotor, non locomotor, and manipulative. Tools: box (2), ribbon (5), leader $5 \mathrm{~m}$ (1), cone cones (4), (3) tiptoe, (4) jump frog.

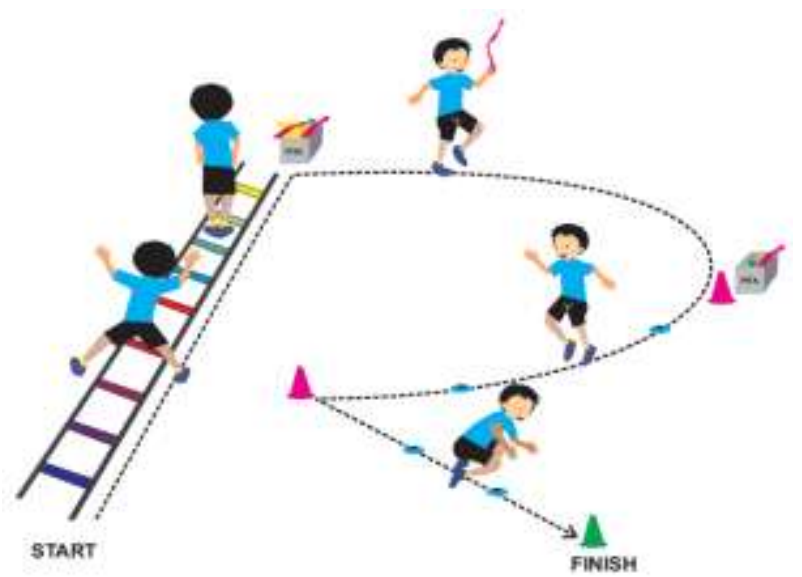

Figure 6. Sirkuit R

\section{E Circuit}

Target: locomotor, non locomotor, and manipulative. Tools: (1) 5 pieces of marker, (2) 8 pieces of cones, (3) meters, (4) 4 green circles, (5) smile balls 4 pieces, (6) 1 fruit box, (7) hop hula 3 fruit, (8) whistle. Play area: 7 x 5 meters. Procedure: (1) The student takes the smile ball in the box then walks towards post 2 while squeezing the ball, (2) By holding the ball of smile, the student jumps with his right foot towards post 3 then walks around the marker and jumps back using his left foot, (3) After arriving at post 2 again, the student walks to the hamlet and jumps on two legs then walks around the marker and jumps back with 2 feet to the first hulu and then heads to post 1 to turn left towards post 5 while moving the ball to right and left hands alternately by circling the marker, and ending in post 1 again, the second student follows after the first student arrives at post 2 . bowl cones (9). Play area: 7 x 4 meters. Procedure: students do: (1) open and close jump, (2) play ribbon up and down,

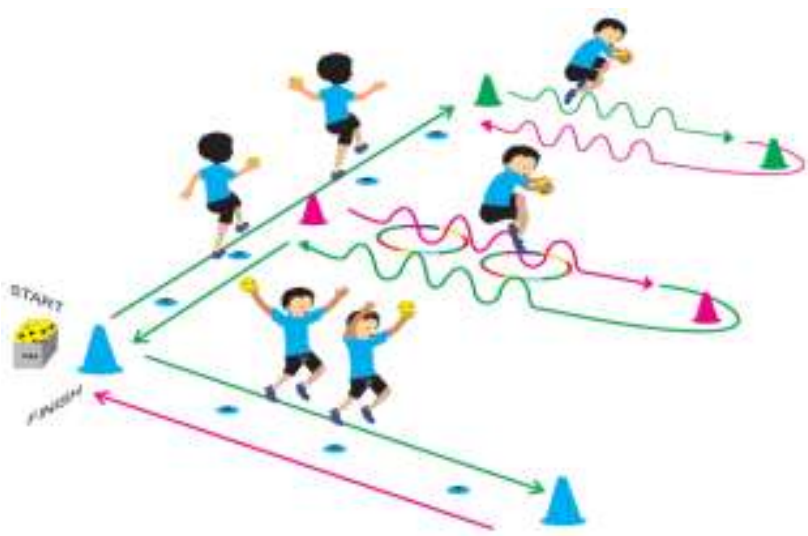

Figure 7. Sirkuit E

\section{8. $\quad$ N Circuit}

Target: locomotor, non locomotor, and manipulative. Tools: bowl cones (3), cone cones (7), ribbons (5), basketball (5), paralon $20 \mathrm{~cm}$ (3), boxes (2). Play area: 7 x 5 meters. Procedure: students do: (1) zigzag run, (2) walk while playing a ribbon (right then left), (3) frog jump, (4) ball clip on the waist, hand touching the foot in the direction of the ball twice.

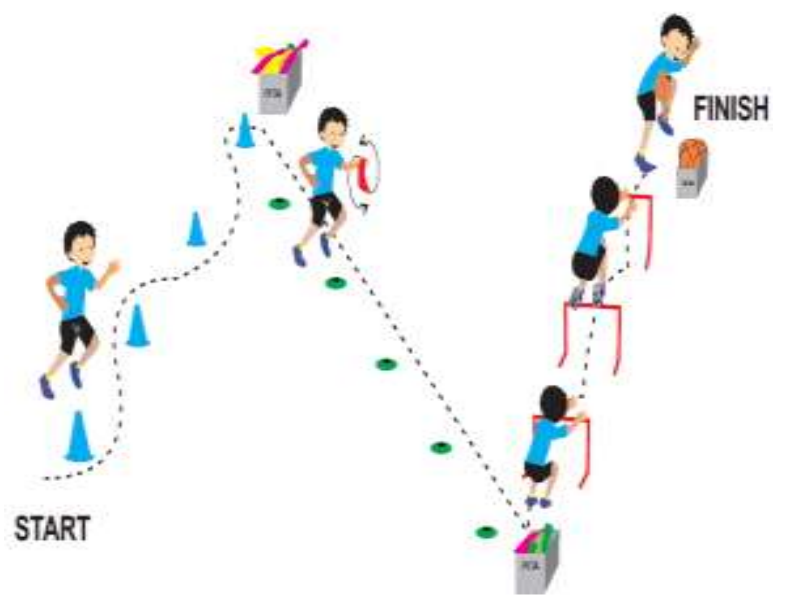

Figure 8. Sirkuit N

\section{METHODOLOGY}

We used the pretest-posttest control group design to explore the effects of physical activity "children's circuit models" based blended learning for kids endurance.

The research sample consisted of 49 students first grade elementary school of IT Darussalam Cikarang, Bekasi Regency and accompanied by their parents. The study was conducted for 1 month. Child endurance test uses modification Harvard steps test with 0.974 validity and 0.970 reliability. Following are the procedures for implementing Harvard steps test. Objective: to measure cardiorespiratory resistance.

1. Tools: bench / box as high as $30 \mathrm{~cm}$, whistle, form test results $\&$ pens.

2. Implementation: (1) the testor gives the command "ready", when the whistle is blown, the testes go up and down the bench until they can, the legs must be straight when on the bench, and if riding with the right foot then go

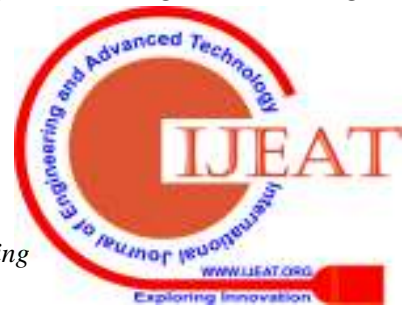


down also with the feet right.

3. Assessment: The results of the tests recorded are the numbers obtained when riding the bench completely.

Analyze technique using IBM SPSS for Windows 21 with normality test using kolmogorof smirnov, and homogeneity test using Levene test. The analysis test used in this research is the average difference test using t-test (paired t-test and independent $\mathrm{t}$-test).

\section{RESULT AND DISCUSSION}

\section{A. RESULT}

E-learning learning materials Motor Learning "Children Circuit Model" can be run using edmodo, the initial display will appear to $\log$ in. The following is a blended learning display image on the edmodo.com website.

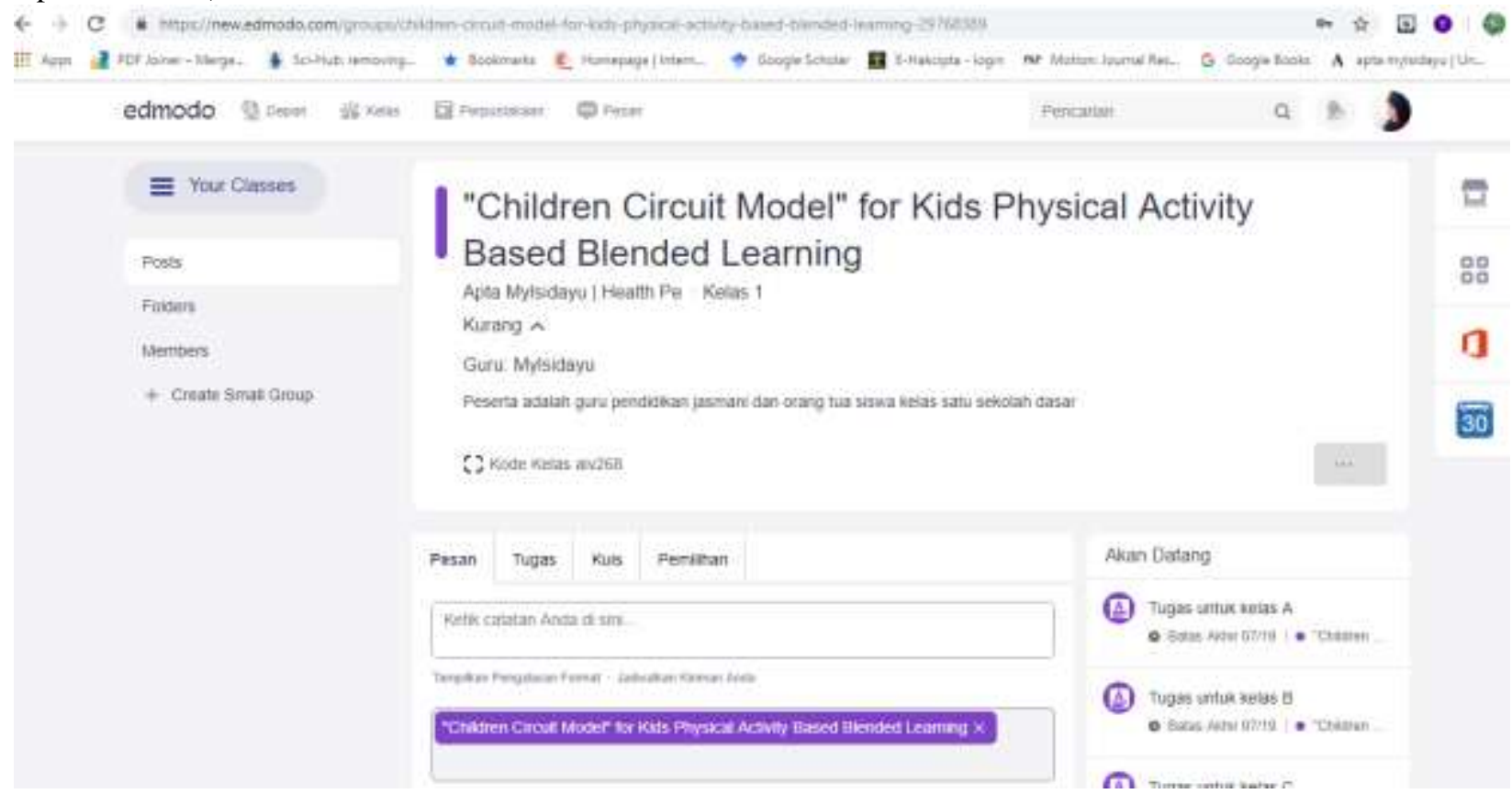

Figure 9. Learning physical education (physical activity) through blended learning.

Students study the material that has been uploaded. Then they will practice the Children Circuit Model to the children by asking for help from parents in their teaching practice to learn the material that has been uploaded. Furthermore, students who are practicing teaching hold meetings to parents. He explained the process of learning blanded learning to parents and helping parents to register on the edmodo.com website.

This study aims to determine whether "children circuit model" for physical activity of children based on blended learning can influence children's endurance. It is hoped that, with the "children circuit model" based on blended learning, physical education teachers can see the learning of children's physical activity through the edmodo site indefinitely. Then, physical education teachers and parents who have applied this physical activity to children can share information, and discuss physical activity after being done in the field.

"Children Circuit Model" is the result of research on children's physical activity in the form of the word "Children". Each letter consists of 3 or 4 physical activities in the form of a combination of basic locomotor, non locomotor, and manipulative movements. The Children Circuit Model is the result of research and development and has been tested for first grade students in elementary school and is suitable for use.

The children's circuit model for kids physical activity based blanded learning is carried out by teachers with the help of parents. The teacher controls students through parents by communicating on the Edmodo website.

Before being given "children circuit model" for kids activity based blanded learning, students do the initial test with modification Harvard steps test. Then, divided into two groups namely the experimental group and the control group. The following are the results of the normality test in the study.

Table 1. normality test result

\begin{tabular}{|c|c|c|c|c|c|}
\hline & & $\begin{array}{l}\text { wejestedp } \\
\text { enmurt }\end{array}$ & $\begin{array}{l}\text { posulast eat } \\
\text { miment }\end{array}$ & $\begin{array}{l}\text { ans Jest wirt } \\
\text { not }\end{array}$ & bos fest it \\
\hline n & & 25 & 25 & 24 & 24 \\
\hline \multirow[t]{2}{*}{ Huna Parstithes"b } & then & 246809 & 357200 & 320013 & अ9t6T \\
\hline & St1 Deataton & 595001 & 7.16194 & 9.77952 & 1057955 \\
\hline \multirow[t]{3}{*}{ Mast Eitame to Riretes } & Ratrils & 121 & 165 & 190 & 178 \\
\hline & Fostie & 321 & 108 & 150 & .175 \\
\hline & Aagkth: & -128 & -105 & IIT: & -130 \\
\hline Tust Stantu: & & 141 & 165 & 150 & 125 \\
\hline Ascme sie Golen. & & $177^{2}$ & $976^{\circ}$ & $175^{5}$ & $.655^{2}$ \\
\hline
\end{tabular}

The significance value of the experiment group with pre test 0.177 and post test $0.078(\mathrm{p}>0.05)$, while the control group pre test 0.175 and post test 0.055 ( $p>0.05)$. Based on the Kolmogorov-Smirnov normality test the data are normally distributed.

The significance of the pre test homogeneity of $0.170>$ 0.05 indicating that the pre test variables in the experiment and control groups are homogeneous, and the significance of the post test $0.106>0.05$ indicates the homogeneous post test variables in the experiment and control groups. 
International Conference on Recents Advancements in Engineering and Technology (ICRAET-18) |15th and 16th March 2019|Siddhartha Institute of Technology \& Sciences, Telangana, India

Table 2. Description of experiment and control group data

\begin{tabular}{lllll}
\hline Indicator & \multicolumn{2}{l}{ Experiment group } & \multicolumn{2}{l}{ Control group } \\
\cline { 2 - 5 } & Pre test & Post test & Pre test & Post test \\
\hline Mean & 24.68 & 35.72 & 32.08 & 36.91 \\
SD & 5.9 & 7.16 & 9.77 & 10.57 \\
Max & 34 & 52 & 50 & 55 \\
Min & 14 & 24 & 20 & 25 \\
\hline
\end{tabular}

Based on the table above, the overall comparison can be seen from the standard deviation, variance, min, and the max post test is greater than the pre test.

Table 3. Independent $t$ test

\begin{tabular}{llll}
\hline $\begin{array}{l}\text { Children circuit } \\
\text { model }\end{array}$ & $\begin{array}{l}\text { Mean } \\
\text { difference }\end{array}$ & t & $\begin{array}{l}\text { Sig. (2- } \\
\text { tailed) }\end{array}$ \\
\hline $\begin{array}{l}\text { Experiment_group } \\
\text { Control_group }\end{array}$ & -11.040 & -5.949 & 0.000 \\
\hline
\end{tabular}

Table 3 displays the independent $\mathrm{t}$ test of experiment group shows a 2-way (t-tailed) significance value $0.000<$ 0.05 , and control group shows $0.107>0.05$. Independent $t-$ test revealed significant difference between pre test and post test in experiment group, but no significant difference between pre test and post test in control group.

Table 4. Paired t-test analysis of mean difference

\begin{tabular}{lllll}
\hline \multicolumn{2}{l}{ Children circuit model } & $\mathrm{t}$ & $\mathrm{df}$ & $\begin{array}{l}\text { Sig. (2- } \\
\text { tailed) }\end{array}$ \\
\hline Experiment_group & $\begin{array}{l}\text { Pretest_ } \\
\text { posttest }\end{array}$ & - & 24 & 0.000 \\
Control_group & $\begin{array}{l}\text { Pretest_ } \\
\text { posttest }\end{array}$ & 14.742 & 23 & 0.000 \\
\hline
\end{tabular}

Paired t-tests revealed significant differences between pretest and posttest $(\mathrm{p}<0.05)$ for kids endurance. This shows that there is a significant effect on the differences in treatment given to each experiment and control group.

\section{B. DISCUSSION}

Pollard and Triggs (1997) define learning as a process in which skills, attitudes, knowledge, and concepts can be learned, understood, applied, and developed. Learning is defined as a deliberate effort by educators to support student learning activities (Kusumandari \& Istyarini, 2015).

"Circuit Learning models are a model that maximizes the empowerment of thoughts and feelings with adding and repetition patterns. "This model aims to make students more easily capture the subject matter delivered by the teacher

A shift is needed for teachers to consider the whole curriculum and a 'weaving through', rather than 'tacking on', of blended learning approaches. However, effective blended learning design is only part of what is required for successful learner centred blended learning (de GeorgeWalker \& Keeffe, 2010).

Circuit training was a safe intervention, and no serious adverse events were reported (Van De Port, Wevers, Lindeman, \& Kwakkel, 2013). This statement is supported by the results of research that show a positive impact on the resilience of children. with blanded learning methods, parents at least have free time to play with children because they accompany their children to do physical activities at home. So, "children circuit model" for kids physical activity based blended learning can be used as a reference in teaching physical education for first grade students in primary school because this model provides an increase in kids endurance.

\section{CONCLUSION}

In conclusion, there was a significant increase in physical activity in both the experimental group and the control group $(0.00<0.05)$, but "children circuit model" for kids based on physical activity blanded learning was more effective than the control group, because students did not only carry out physical activities during physical education. but it can be repeated at home with the help of parents.

These results suggest that endurance, as a measure of physical activity intensity, should be closely monitored during research that is intended to make inferences about its the effects "children circuit model" as participation in vigorous activities have specific benefits for body over lower intensities.

Concentration is influenced by endurance. Because if a person's endurance is not good, then he will easily experience fatigue and drowsiness. The better the child's endurance, the better the level of concentration.

\section{ACKNOWLEDGMENT}

Thank you to Ministry of Research, Technology and Higher Education of the Republic of Indonesia as a sponsor, students and parents of first grade elementary school, the Principal of the School of IT Darussalam Cikarang Bekasi Regency, Indonesia.

\section{REFERENCES}

1. Warburton, D.E., Nicol, C., and Bredin, S.S. 2006 a Health benefits of physical activity: the evidence. Can. Med. Assoc. J. 174: 801-809. doi:10.1503/cmaj.051351

2. Mandic, S., Bengoechea, E. G., Stevens, E., Leon de la Barra, S., \& Skidmore, P. (2012). Getting kids active by participating in sport and doing It more often: focusing on what matters. International Journal of Behavioral Nutrition and Physical Activity. https://doi.org/10.1186/1479-5868-9-86

3. Trost, S. G., Kerr, L. M., Ward, D. S., \& Pate, R. R. (2001). Physical activity and determinants of physical activity in obese and non-obese children. International Journal of Obesity. https://doi.org/10.1038/sj.ijo.0801621

4. Tappe, K. A., Glanz, K., Sallis, J. F., Zhou, C., \& Saelens, B. E. (2013). Children's physical activity and parents' perception of the neighborhood environment: Neighborhood impact on kids study. International Journal of Behavioral Nutrition and Physical Activity. https://doi.org/10.1186/1479-5868-10-39

5. Oliver, M., Witten, K., Kearns, R. A., Mavoa, S., Badland, H. M., Carroll, P., ... Ergler, C. (2011). Kids in the city study: Research design and methodology. BMC Public Health. https://doi.org/10.1186/1471-2458-11-587

6. Castelli, D. M., Hillman, C. H., Hirsch, J., Hirsch, A., \& Drollette, E. (2011). FIT Kids: Time in target heart zone and cognitive performance. Preventive Medicine. https://doi.org/10.1016/j.ypmed.2011.01.019

7. Mylsidayu, A. (2019). The Influence of Cardio Workout to Aerobic Endurance. https://doi.org/10.2991/icssh18.2019.7

Published By:

Blue Eyes Intelligence Engineering

\& Sciences Publication 
8. Jones, A. M., \& Carter, H. (2000). The effect of endurance training on parameters of aerobic fitness. Sports Medicine. https://doi.org/10.2165/00007256200029060-00001

9. Hanif, A. S. (2015). Kepelatihan dasar sepak takraw. Jakarta: Rajawali Pers

10. Bruce Joice, Marsha Weil, and E. C. (2009). Models of Teaching. Yogyakarta: Pustaka Pelajar

11. Branch, K. L. G. dan R. M. (2002). Survey of Instructional Development Models, Fourth Edition. New York: Syracuse University

12. Rita C. Richey, James D. Klein, and M. W. T. (2012). Rita C. New York: Routledge

13. Gagne, R. M. (2005). The Condition of Learning and Teori of Instruction. New York: Holt Rinehart and Winston, Inc

14. Dick, W and Carrey, L. (1985). The Systematic Design Instruction. Secon edition. Glenview. Illinois: Scott., Foreman and Company

15. Reigeluth, Charles M. (2016). Instructional-Design Theories and Models; An Overview of their Current Status. Hilsdale, New Jersey: Syracuse University

16. Kemp, J.E, Morrison, G.R \& Ross, S.V. (2004). Design Effeective Instruction. (4th Ed). New York: John Wiley \& Sons

17. Evelyn Kigozi Kahiigi. (2008). Exploring the e- Learning state of art. Electronic Journal E-learning, 6(2), 1

18. Michael, A. (2013). Michael Allen's Guide to E-learning. Canada: John Wiley \& Sons

19. Darmayanti, T. (2007). E-learning in Distance Education: Concepts That Change Learning Methods in Higher Education in Indonesia. Jurnal Pendidikan Terbuka Dan Jarak Jauh, 8(2), 3

20. Oliver, M., \& Trigwell, K. (2005). Can "Blended Learning" $\quad \mathrm{Be} \quad$ Redeemed? E-Learning https://doi.org/10.2304/elea.2005.2.1.2

21. Tyley, S. (2012). Blended learning. Fire Risk Management.

22. Garrison, D. R., \& Vaughan., N. D. (2008). Blended Learning in Higher Education: Framework, Principles, and Guidelines. San Francisco: Jossey-Bass

23. Horn, M. B., \& Staker, H. (2015). Blended: Using Disruptive Innovation to Improve Schools. San Francisco: Jossey-Bass

24. Garrison, D. R., \& Kanuka, H. (2004). Blended learning Uncovering its transformative potential in higher education. Internet and Higher Education. https://doi.org/10.1016/j.iheduc.2004.02.001

25. Macdonald, J. (2008). Blended learning and Online Tutoring: Planning Learner Support and Activity Design. Hampshire: Gower Publishing Limited

26. Thorne, K. (2003). Blended learning: How to Integrate Online and Traditional Learning. London: Kogan Page Limited

27. Khe, F. H., \& Cheung., W. S. (2014). Using Blended learning: Evidence-Based Practices. (Springer, Ed.). London

28. Pollard A \& P Triggs 1997. Reflective teaching in secondary education. London: Cassell.

29. Kusumandari, Rafika Bayu \& Istyarini, Character Education Development Model-based E-Learning and Multiple Intelegency in Childhood in Central Java, Global Journal of Computer Science and Technology: $H$ Information \& Technology Volume 15 Issue 3 Version 1.0 Year 2015

30. de George-Walker, L., \& Keeffe, M. (2010). Selfdetermined blended learning: A case study of blended learning design. Higher Education Research and Development. https://doi.org/10.1080/07294360903277380

31. Van De Port, I. G. L., Wevers, L. E. G., Lindeman, E., \&
Kwakkel, G. (2013). Republished research: Effects of circuit training as alternative to usual physiotherapy after stroke: Randomised controlled trial. British Journal of Sports Medicine. https://doi.org/10.1136/bjsports-2012e2672rep

\section{AUTHORS PROFILE}

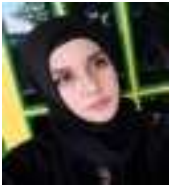

Apta Mylsidayu. Doctoral Student, Postgraduate, Universitas Negeri Jakarta, Jakarta, and lecture Universitas Islam 45 Bekasi, West Java, Indonesia. Write a book with the title; Psikologi Olahraga, llmu Kepelatihan Dasar, and Mental Training: aspek-aspek psikolog i dalam olahraga. E-mail: mylsidayu@gmail.com

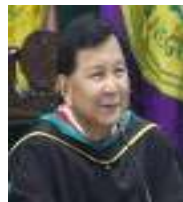

James Tangkudung. Proffesor Universitas Negeri Jakarta, Indonesia. Write a book with the title; Kepelatihan olahraga; pembinaan prestasi olahraga, Ilmu Faal (Fisiologi), Metodologi Penelitian Kajian dalam Olahraga; Macam-Macam Metodologi Penelitian: Uraian dan Contohnya, Paragames Paralympic, and Mental Training; aspek-aspek psikologi dalam olahraga.

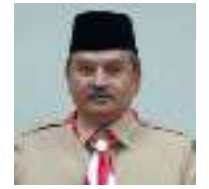

Achmad Sofyan Hanif. Proffesor Universitas Negeri Jakarta, Indonesia. Write a book with the title; Kepelatihan Dasar Sepak Takraw, Sepaktakraw untuk pelajar, Sepaktakraw Basic Training, Kepelatihan Dasar Sepaktakraw, Sepaktakraw Pantai, and Falsafah, pengukuran dan Teknik Dasar Shorinji Kempo.

Bujang. Doctoral Student, Postgraduate, Universitas Negeri Jakarta, Jakarta, and lecturer Universitas Islam 45 Bekasi, West Java, Indonesia.

Dindin Abidin. Doctorates Universitas Islam 45 Bekasi, West Java, Indonesia. Write a book with the title; Sosiologi Olahraga, Biomekanika, Ilmu Gizi, and Ilmu Kesehatan. 